CZU821.135.1-1.09

https://doi.org/10.52505/filomod.2021.15.16

\title{
SIMONA POPESCU SAU POEZIA ÎN DIALOG
}

\author{
CRistina DICUSAR \\ Institutul de Filologie Română „B. P.-Hasdeu” al MEC
}

Rezumat. Prezenta comunicare propune o lectură a poeziei Simonei Popescu din perspectiva raportului autor-text-cititor. Vom urmări care sunt elementele și strategiile textuale care se află sub cupola acestui efort de a produce efect asupra cititorului (un cititor ipotetic sau nu), vorbind despre corporalitate, și „transferul de corporalitate" in cadrul poeticii autoarei; cu alte cuvinte, despre autenticitatea scriiturii. In cadrul acestui text ne vom referi la „Xilofonul și alte poeme” (1990), „Juventus” (1994) (reeditat în 2004), „Noapte sau zi” (1998), și „Lucrări în verde: pledoaria mea pentru poezie" (2006)

Cuvinte-cheie: dialog, intimitate, biografism, poezie tranzitivă, autenticitate.

Abstract. This article offers a short analysis of Simona Popescu's poetry from the perspective of the dialogue between the author, the text, and the reader. We will identify the textual elements and strategies that help the author interact with the reader through the text. We will focus on corporality, and the „transfer of corporality" within the poetics of the author. In this text we will refer to the poetry books: „Xilofonul și alte poeme” (1990), „Juventus” (1994) (reprinted in 2004), „Noapte sau zi” (1998), and "Lucrări în verde: pledoaria mea pentru poezie" (2006). authenticity.

Keywords: dialogue, intimacy, corporeality, biography, transitive poetry,

\section{Introducere}

Simona Popescu este una dintre exponenții de bază ai nouăzecismului. A debutat în $1990 \mathrm{cu}$ „Xilofonul și alte poeme”, apoi a publicat în volumul colectiv „Pauză de respirație” (1991), alături de colegii săi din „grupul de la Brașov": Andrei Bodiu, Marius Oprea și Caius Dobrescu; urmează volumul de poezii ,Juventus” (1994) (reeditat în 2004) și, în 1997, romanul „Exuvii”, urmat de cartea de poezii onirice „Noapte sau zi” (1998), apoi „Lucrări în verde: pledoaria mea pentru poezie" (2006). A publicat și cărți de critică literară și eseu: „Volubilis” (1998), „Clava. Critificțiune cu Gellu Naum” (2004), „Autorul, un personaj” (2015). În 2021 este editată „Opera Poetică” a autoarei la editura ROCART.

1 Acest text este scris înainte de a ajunge și la noi proaspăt apăruta „Opera Poetică” a autoarei (publicată în 2021, la editura ROCART) și „Cartea plantelor și animalelor" (în curs de apariție). 
Una dintre întrebările firești, nu întotdeauna verbalizate, pe care și-o adresează un cititor atunci când descoperă un text cu care rezonează este: cum $s$-a stabilit această conexiune dintre mine (cititorul) și autor/,,corpul' textual? . O ,perpetuă tovărășie amicală” (Simion, 1982, p. 109), o complicitate dintre autor și cititor însoțește o lectură asumată, tovărășie care implică empatia autorului față de cititor și receptivitatea cititorului față de text.

Umberto Eco ne vorbește despre cooperarea dintre cititor și scriitor ca strategie generativă a textului (Umberto Eco, Lector in fabula), sugerând faptul că orice scriere literară are la bază prezumția că aceasta va fi citită, textul fiind, așadar, mai întâi pretextul adresării. Ideea de cititor ,pitit” în faldurile textului a fost reluată de nenumărate ori nu doar la Umberto Eco, ci și la T. S. Eliot, Carlos Bousono ș. a., indiferent de ,situația textuală” în care nimerește acest cititor (genul, specia, curentul sau fenomenul literar). Cititorul capătă astfel rolul de dublu al autorului. În cazul poeziei tranzitive, acest dublu ,îsisi arogă prerogativele unui cenzor plin de ambiții.” (Crăciun, 2017, 398 p.).

Intr-un interviu pentru revista Contrafort, întrebată despre cititorul ipotetic și rolul acestuia în textele ei, Simona Popescu spune: „Când scriu despre alții, o fac ca și cum ar putea să mă citească” (Popescu, 2018). Extrapolând, a scrie despre sine ar presupune aceeași responsabilitate a autorului în rolul de critic-cititor. Un rol pe care și-1 asumă Simona Popescu.

În cele ce urmează nu vom vorbi despre problematica și teoriile receptării, ne vom axa însă pe câteva caracteristici ale poeziei Simonei Popescu, caracteristici care facilitează acest dialog autor-cititor.

\section{Autorul și textul}

Atitudinea autoarei faţă de text este aşadar similară atitudinii unui regizor față de o reprezentație scenică, îndeplinind multiple roluri: cel de critic, de spectator, dar și cel de călăuză. Eul auctorial pornește însă mereu de la sine, de la întrebări de tipul „Care e locul meu? Eu cum mă apăr? Ce vreau eu să fac?" (Crăciun, 2018. p. 349), (am adăuga și cine sunt eu?) încercând să ajungă în miezul acestora, deschizând un dialog pe mai multe voci și planuri, cu sine și cu lumea, o lume interiorizată, corporală.

Conflictul principal elucidat în poezia Simonei Popescu își află temelia pe paradoxul ,voinț[ei] de identitate și dorinț[ei] de inocență" (Crăciun, 2018. p. 352), conflict care se rezolvă vertical, prin suprapunerea planurilor/eurilor. „Ieșirea din uniplan” înseamnă, la autoare, o scufundare în adâncurile ființei. Eul auctorial e un ,scafandrier” (,,pătrund în minte și în gând/ca un scufundător noaptea în mare" (Popescu, 1994, p.8)) al cărui scop ar fi întâlnirea cu acea „tânără ființă [care] se joacă plutește vioaie/și fără costum de protecție" (Popescu, 1994, p. 8), adică o apropiere de eul inocent (un eu eliberat de memorie), ,arhetipul infans" (Sora, 2008, p. 261).

Această abordare este, paradoxal, cerebrală, un,,spirit critic inconștient" (Popescu, 1998, p. 44), după cum punctează autoarea, e călăuza care ghidează cititorul în vederea developării unor „secrete” și conflicte interioare (,secrete” care nu pot fi decât comune, repetabile). Autenticitatea derivată din acest efort 
„se revendică tocmai din această poetică a intimității” (Encică, 2015, p. 128) cu sine și, prin extensie, cu cititorul.

\section{Biografism și corpo-r(e)alitate}

În primul volum, „Xilofonul și alte poeme”, Simona Popescu începe de la o poetică a cotidianului și trece, în alte volume, odată cu diversificarea lecturilor $^{22}$ (și în virtutea apropierii autoarei de personalitatea lui Gellu Naum), la un tot mai mare interes pentru poetica suprarealistă.

„Percepția cotidianului și pulsiunile subconștientului par să fie valori ce se exclud reciproc. Nu și în cazul în care acești stimuli sunt valorizați literar prin concentrarea asupra acestei fascinante entități plurale care este corpul.” (Crăciun, 2018. p. 353).

Totuşi, nu putem vorbi doar de un singur corp, ci de mai multe. Aceste corpuri amintite (,cu ce trup cu ce trup mai simțim mai simțim cele trecute?” (Popescu, 1990, p. 17), reconstituite în text, alcătuiesc realități ,,care nu [pot] fi povestit[e].” (Crăciun, 2018, p. 355), de aici lipsa de narativitate și dialogul caleidoscopic între niște euri pulverizate și recompuse: „sunt un desen de Escher din care nu mai ies/ mă tot despart de mine și iar mă întâlnesc" (Popescu, 1998, p.34) sau, scriind despre un vis: „Imi tot spuneam ceva eu mie/ tot explicam acolo lângă mine sofisticat/ce se petrece la distanță/mi se părea ciudat/stăteam în jurul unei mese/ eram vreo șapte Ființe-Eu/ cu-o căpetenie tânără în frunte" (Popescu, 1998, p. 62).

Aceste „nenumărate identități, toate la fel de reale și de importante" (Crăciun, 2018, p. 355) comunică într-un ,prezent absolut” (Crăciun, 2018, p. 355), un timp suspendat (la fel celui folosit de suprarealiști (Crăciun, 2018, p. 355)), un kairos extins (din greacă, kairos = momentul oportun, șansa), un timp oprit prin text. Un timp care este și al seducției scripturale; seducție care are loc, indirect, ,printr-un tip special de egocentrism, de egotism, mai degrabă, consubstanțial creației. O carte bine scrisă nu va fi niciodată focalizată asupra celui care citește" (Crăciun, 2018, p. 87). Totuși, în secundaritatea lui, cititorul devine principal prin identificare.

In-corporarea amintirilor și viselor într-un text: „Ceea ce-mi place la cărțile adevărate, la amintiri și vise este că nu mint./ incorporatul vis/ încorporatul vis" (Popescu, 1998, p. 50), devine metoda de acces la autenticitatea scripturală. Autenticitate care devine canalul de comunicare cu cititorul; textul fiind, așadar, o invitație într-un joc de oglinzi, în care corpurile „mentale” (ale autorului? ale cititorului?) se confundă. Astfel, corpul textual poate deveni, în timpul lecturii, al cititorului.

2 ,încă de la primele ei texte poeta se afla, parcă fără să știe, în căutarea unei metafizici personale, a unor puncte de stabilitate care să facă suportabile propriile-i exuvieri. (...) Sigur este că la un moment dat, prin revizitarea insistentă a vechilor obsesii, prin lărgirea progresivă a plajei de lecturi, cadrele poeticii originare s-au dovedit prea înguste, iar ideologia poeziei cotidianului - la care poeta subscrisese cu entuziasm - prea săracă)" p. 352 (Crăciun, Gheorghe. Pulsul prozei. Iaşi, ed Polirom, 2018. 379 p.) 
La Simona Popescu găsim mai multe straturi comunicante, mai multe tipuri de dialog, o prezență a oralității și acea „vitalitate sintactică a comunicării uzuale" despre care vorbea Gheorghe Crăciun: straturi în care vocea auctorială face o conexiune-identificare cu cititorul $(\mathrm{eu}=\mathrm{tu}=\mathrm{eu})$ (,despre mine, dar mai ales despre tine june deoriundeșioricum” (Popescu, 1994, p.11), straturi în care confruntarea cu sine ne provoacă empatie

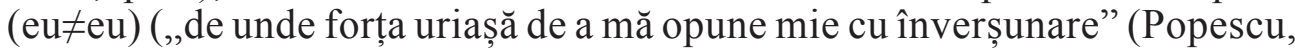

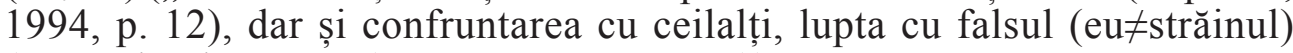
(,nu-s de-al vostru” (Popescu, 1994, p. 20)).

\section{Oralitate și reiterări. Elemente teatrale în poezia Simonei Popescu}

Începând de la „Xilofonul și alte poeme” și, mai târziu, în „Juventus”, „Noapte sau Zi”, dar și, mai ales, în „Lucrări în verde. Pledoaria mea pentru poezie" (care include și texte formatate ca poem), autoarea folosește tot mai multe figuri retorice, iar adresările de tipul ,prietene, ia-mă cum sunt/ajută-mă" (Popescu, 1994, p. 10) sau „Bătrâne prieten/ ia-mă cu tine/ doar înțelegerea ta mă poate îmblânzi" (Popescu, 1994, p.43), sunt la locul lor.

Dialogul autor-text-cititor are loc și prin revenirile de la carte la carte, de la poem la poem, reveniri tematice, dar și prin repetiții ca „elemente structurale esențiale” (K. Le Guin, p.203) Ursula K. le Guin vorbește despre capacitatea organismelor umane de a mima ritmul celui ce ne vorbește, repetând nu doar gesturile, mimica, ci și ritmul respirației, până și ritmul cardiac. În ajutor discursului său, vorbitorul, folosește repetiția, structurându-și comunicarea astfel încât ideea principală să fie reluată într-o formă sau alta. În literatură, mai ales în poezie, se utilizează elemente ale oralităţii (ritmul, rima, repetiţiile, reiterările) chiar dacă este utilizată o oralitate de tip secundar, indirect, aceste elemente sunt direcționate către eul-cititor. Cititorul astfel este angajat în ritmul poemului-carte (Simona Popescu optează mai ales pentru structura poem-carte (termen folosit de Nicolae Leahu), în defavoarea cărții de poezie).

În poezia de tip tranzitiv, discursul devine mai direct, orientat către un cititor care nu are expectativa reflexivităţii: „Poezia tranzitivă se adresează unui cititor care trăiește în imediat și este obligat să țină seama de configurația acestui context. Ea încearcă să incorporeze în substanța ei rapiditatea, disjuncția planurilor, simultaneitatea, aleatorismul, artificialitatea și multiplicitatea existenței, oralitatea, vitalitatea sintactică a comunicării uzuale." (Crăciun, 2017, p. 403) În textele Simonei Popescu urmărim acest tip de discurs tranzitiv, mai ales în exprimarea disjuncțiilor planurilor existențiale.

O temă de discuție aparte ar fi această repetiție/reiterare în poezia Simonei Popescu. Autoarea lucrează cu inconștientul, care „este și el prin natură diferențial și iterativ, serial, problematic și interogator." (Deleuze, Diferență și repetiție, p. 164), revenind și insistând asupra unor întrebări sau probleme-cheie: „Cum de-mi aduc aminte atât de puțin?/ (Cum de-mi aduc aminte?)/ Fără de rost este și amintirea/ cum fără de rost multe lucruri sunt/ mai ales când nu e adevărată/ mai ales când e altceva/ mai ales când nici nu 
mai e a ta/ când nu o mai înțelegi/ când nu se mai potrivește cu tine/ când îți pune la încercare puterea și te umilește" (Popescu, 1990, p. 17)

Iterativitatea în poemele Simonei Popescu denotă o preocupare obsesivă faţă de mecanismele amintirii și diferitele tipuri de corpuri mentale coexistând într-un singur corp fizic. O conceptualizare poetică a temei identitare, prin iterare, este propusă de autoare în unul din ultimele poeme publicate în revista „Apostrof”: „,fiecare frunză mică îşi are / model în frunza cea mare / care e, prin repetiţie, cu totul / ea însăşi." (Popescu, Apostrof, http://www.revista-apostrof.ro/arhiva/an2021/n9/a14/). Astfel, identicul, reiterat, devine Eu, un eu autentic-adevărat.

\section{Referințe bibliografice:}

1. Crăciun, Gheorghe, Aisbergul poeziei moderne. Iași, ed. Polirom, 2017. 686 p.

2. Crăciun, Gheorghe. Pulsul prozei. Iași: editura Polirom, 2018. 379 p.

3. Dan C. Mihăilescu, ,Sorbitor”, în 22, nr. 10, 10-16 martie, 1998, p.15.

4. Encică, Victorița. Dialectica ființei-de-aici cu ființele-de-acolo în proza Simonei Popescu*, p. 128-134 https://litere.ucv.ro/litere/sites/default/files/litere/ Cercetare/Activitate stiintifica/Analele Facultatii de Litere/CIC2015.pdf

5. Gilles Deleuze „Diferență și repetiție”, - București: Editura Babel, 1995, 488 p.

6. Pauză de respirație [Text tipărit] / Andrei Bodiu, Simona Popescu, Caius Dobrescu, Marius Oprea. - Ed. a 2-a . - Bucureşti: Tracus Arte, 2011, 64 p.: il.

7. Popescu, Simona, Interviu cu Simona Popescu - Thereminul, hypertextul, peștele-curcubeu și licăririle, http://www.contrafort.md/categorii/interviu-cu-simonapopescu-thereminul-hypertextul-pe-tele-curcubeu-i-lic-ririle

8. Popescu, Simona, Juventus, [Text tipărit] / Simona Popescu . - Bucureşti: Cartea Românească, 1994, 126 p.

9. Popescu, Simona, Lucrări în verde sau pledoaria mea pentru poezie, [[Text]]. - Bucureşti: Cartea Românească, 2006 . - 333 p. + CD.

10. Popescu, Simona, Noapte sau zi, [Text tipărit]: Poem / Simona Popescu .Piteşti: Paralela 45, 1998, 80 p.

11. Popescu, Simona, Poezia mea e un raport între mine şi ,poezia' neaşteptată a lumii, http://www.contrafort.md/old/2002/87-89/281.html

12. Popescu, Simona, Xilofonul sau alte poeme, [Text tipărit] / Simona Popescu Bucureşti: Editura Litera, 1990, 55 p.

13. Simion, Eugen. Întoarcerea autorului. Eseuri despre relația creator-operă. București, ed. Cartea Românească, 1982. 472 p. $294 \mathrm{p}$.

14. Sora, Simona. Regăsirea intimității. București, Cartea Românească, 2008,

15. Umberto Eco, Lector in fabula: Cooperarea interpretativă în textele narative. București: Univers, 1991. 308 p.

16. Ursula K. Le Guin, „The Wave in the Mind: Talks and Essays on the Writer, the Reader, and the Imagination”, Publisher: Shambhala, Year: 2004.

Notă: Articolul a fost realizat în cadrul proiectului de cercetare 20.80009.1606.03 Contexte socioculturale autohtone şi interconexiuni europene în creaţia populară şi literatura cultă din Basarabia (sec. XIX până în prezent), Institutul de Filologie Română „B. P.-Hasdeu” al MEC. 